\title{
A New Continuous Cell Line from the Mosquito Psorophora confinnis (Diptera: Culicidae) and its Susceptibility to Infections with Some Arboviruses
}

\author{
Felio J Bello/ ${ }^{+}$, Jaime A Rodríguez, Jesús Escovar, Víctor A Olano*, \\ Alberto Morales*, Martha González*, Gloria Rey*
}

Departamento de Biología y Química, Universidad De La Salle, Carrrera 2A, No. 10-70, Bogotá, D.C., Colombia *Laboratorios de Virología y Entomología, Instituto Nacional de Salud, Bogotá, D.C., Colombia

A new cell line, PC-0199-BR, was established from embryonated eggs of the mosquito Psorophora confinnis. To date (September 2000) it has had 62 continuous passages. This is the first report of a cell line of mosquitoes belonging to the genus Psorophora. Cell growth initially was achieved in the MM/ VP12 medium, supplemented with $20 \%$ fetal bovine serum; however, the subcultures were later adapted to Grace's medium with $10 \%$ fetal bovine serum. Cell morphology in the primary cultures was heterogeneous; but later in the established cell line, the predominant cell type was epithelioid. Cultured cells were predominantly diploid $(2 n=6)$; however, chromosome abnormalities were observed in a small proportion of the cells in later passages. $C$ and $G$ band patterns were also determined in the karyotype. The cell line isozyme profiles coincided with pupae and adult samples of the species taken from the same colony. A preliminary arbovirus susceptibility study for the cell line was undertaken. No evidence was observed of contamination of the cell line with bacteria, fungi or mycoplasma.

Key words: Psorophora confinnis - cell line - chromosomes - isozymes - arbovirus

Psorophora confinnis (Lynch-Arribalzaga) is a mosquito which has been incriminated as being an efficient vector of the epidemic-epizootic types (IAB and IC) of Venezuelan equine encephalitis (VEE) virus (Sudia 1972). This insect has a wide geographic distribution on the American continent, being found from the northeastern, central and southern regions of the United States to Central America and the Antilles. In South-America it is found throughout much of the continent, extending to the north of Argentina; Ecuador, Peru and Chile being the exceptions (Forattini 1965). There are records of the insect's presence in Colombia in the departments of Norte de Santander, Santander, Tolima, Boyacá, Meta, Huila, Cundinamarca, Córdoba and the Guajira (Olano \& Morales 1981), Arauca (González 1995), Casanare (outbreaks of VEE and Eastern equine encephalitis in Casanare,

\footnotetext{
This work was financed jointly by Colciencias (grant 1243-05-278-97), La Salle University and the Colombian National Institute of Health.

${ }^{+}$Corresponding author. Fax: (57-1)-2868391. E-mail: fbellog@atenea.lasalle.edu.co

Received 23 October 2000

Accepted 28 March 2001
}

Entomological evaluation report, Entomology Laboratory and National Reference Laboratory, Colombian National Institute of Health, 1998) and the Amazon region (Reference Collection, Entomology Laboratory, Epidemiology Subsection and National Reference Laboratory, Colombian National Institute of Health, 1996).

Periodic human VEE epidemics and equine epizootics have occurred in Colombia from the disease's first recognition in 1938 (Sanmartín et al. 1954, 1973, Dickerman et al. 1986). The last report of an epidemic-epizootic occurred in 1995 in the Colombian-Venezuelan Guajira region, in which it was estimated that there were 75,000 to 100,000 human cases; 3,000 had neurological complications and 300 proved fatal. Aedes taeniorhynchus and Ps. confinnis were registered as being the most abundant mosquitoes in the affected zone; from epidemiological evidence, they were incrimated as probable vectors of the virus (Weaver et al. 1996, Rivas et al. 1997).

Insect cell lines have traditionally played a special role in arbovirus studies (Igarashi 1978, Tesh $\&$ Modi 1983), but they have also been used in cocultures for parasite studies (Greany 1991, Leake 1997), to evaluate resistance to insecticides (McCarthy et al. 1987) and as substrates and expression vectors (i.e. baculovirus) to develop biological control strategies (Gelernter \& Federici 1986). In the last few years, the use of molecular 
techniques to study cellular and viral gene in vitro has again stimulated interest in insect cell lines for physiological, biochemical and genetic research (Kurtti \& Munderloh 1994, Shotkoski \& Fallon 1994, Leake 1997).

Since the first cell line was established by Grace (1966), many mosquito cell lines have been established, the greatest number being in the Culicinae subfamily (Kurtti \& Munderloh 1994). However, there were no prior records of cell lines of the Psorophora genus. In 1999, Bello et al. initiated Ps. confinnis primary cell cultures, describing their most significant characteristics; but they were unable to serially subcultured the cells. The present article describes, for the first time, the establishment of a continuous cell line, derived from this mosquito's embryonated eggs. The morphological, cytogenetic and biochemical characteristics and preliminary susceptibility to arbovirus infection are also reported.

\section{MATERIALS AND METHODS}

Mosquitoes - Embryonated eggs were used to initiate the cell cultures; they were taken from a Ps. confinnis colony, established in the La Salle University Entomology Laboratory. This colony was begun from adult and immature forms (larvae and pupae) collected in rice-growing areas near the town of Grenada (in the Meta Department, Colombia) on the 6th, 7th and 8th of November, 1997. The colony has been maintained for 48 successive generations, at an average temperature of $27^{\circ} \mathrm{C}$, $85 \%$ humidity and $12 \mathrm{~h}$ of light.

Specimen sterilization - Approximately 600 to 700 embryonated eggs were placed on moist gauze inside a Petri dish; the eggs were collected from our mosquito colony over a period of 8 to 10 days. They were then washed off the gauze into a $50 \mathrm{ml}$ centrifuge tube by water jet pressure. After removing the water with a Pasteur pipette, $1.6 \%$ sodium hypochlorite solution was added for $10 \mathrm{~min}$. During this period the tubes were repeatedly agitated; then, the hypochlorite solution was removed and $70 \%$ ethanol was added, also being continually agitated for $10 \mathrm{~min}$. Finally, the eggs were washed three times with sterile distilled water (Tesh 1980, Bello et al. 1995). A solution of $0.25 \%$ mercuric chloride in $70 \%$ ethyl alcohol (Hsu et al. 1970) was occasionally used (in the same way) to sterilize the eggs' surface, with an immersion time of 3 min in this solution, followed by two washes with sterile destilled water, containing $100 \mu \mathrm{g} / \mathrm{ml}$ penicillin and $100 \mu \mathrm{g} / \mathrm{ml}$ streptomycin.

Primary culture initiation - Sterile embryonated eggs were rinsed with the growth medium and 1 $\mathrm{ml}$ of the egg mass was put into a $2 \mathrm{ml}$ Ten Broek homogenizer where the eggs were broken mechani- cally. The resulting solution was placed into a 25 $\mathrm{cm}^{2}$ plastic tissue culture flask containing $5 \mathrm{ml}$ of growth medium. This medium was MM/VP12 (Pudney \& Varma 1971), supplemented with 20\% fetal bovine serum (FBS) and a $1 \%$ antibiotic (penicillin and streptomycin) and antimycotic (anphoterycin B) mixture. The cells were kept in an incubator at $28^{\circ} \mathrm{C}$, without additional $\mathrm{CO}_{2}$, and observed daily through an Olympus CK-2 inverted microscope. The primary cultures were fed weekly by adding $2 \mathrm{ml}$ of fresh medium.

Subcultures - The first successful subculture was obtained in January, 1999 and 62 passages have been effected to date. When confluence was reached, the cell monolayer was removed with a rubber policeman. The cells were dispersed by vigorous pipetting and transferred to a new flask containing $5 \mathrm{ml}$ of fresh medium. The first three subcultures were developed at a ratio of $1: 1$, each subcultures with an average duration of 30 days. From the fourth to the 10th passages, subcultures were split at a ratio of 1:2 at 10-day intervals. Thereafter, the split ratio was increased gradually to $1: 10$ and subcultures were made every 8 days.

Growth characteristics - The cultured cells in 24-well plates at log phase were adjusted to a concentration of $2 \times 10^{5}$ cells $/ \mathrm{ml}$. For testing temperature effect, the cells were incubated at $15^{\circ} \mathrm{C}, 20^{\circ} \mathrm{C}$, $25^{\circ} \mathrm{C}, 28^{\circ} \mathrm{C}$ or $37^{\circ} \mathrm{C}$; the effect of different FBS concentrations on cell growth was also determined through the addition of $0,1,5,10$ and $15 \%$ FBS to the medium. The cultured cells were stained with trypan blue and counted daily using a hemocytometer under a microscope.

Cell morphology was observed and photographed using an inverted microscope with phase contrast and an "Olympus" microphotographic system, in increments of 100 to $400 \mathrm{X}$.

Cytogenetics - The chromosomes were prepared using a protocol similar to that of Schneider (1987). Cultures (3-4 days after being subcultured) were incubated with colchicine $(50 \mu \mathrm{g} / \mathrm{ml})$ at a temperature of $28^{\circ} \mathrm{C}$ for $5 \mathrm{~h}$. Then, the cells were separated and submerged in a $0.075 \mathrm{M} \mathrm{KCl}$ hypotonic solution, fixed with glacial acetic acid and methanol (1:3), extended on slides and stained with $2 \%$ Giemsa. The best metaphases from each slide were selected and microphotographed. Twenty metaphases were measured at 3,000X amplification. Eight-day-old cells on air-dried slides were used for the C-banding technique. These slides were submerged in $0.2 \mathrm{~N}$ hydrochloric acid for 10 min. After washing with tap water, the slides were placed in $5 \%$ barium hydroxide for $2 \mathrm{~min}$ at $53^{\circ} \mathrm{C}$, and finally incubated at $55^{\circ} \mathrm{C}$ in $2 \mathrm{XSSC}$ for $1 \mathrm{~h}$. Slides were stained with a $5 \%$ Giemsa solution (Motara \& Rai 1978). For the determination of G- 
banding patterns, the procedure described by Seabright (1971) and Marchi et al. (1980) was used, with some modifications. Slides containing chromosome preparations were used, being submitted to 15 days maturity time. These were incubated for $25 \mathrm{sec}$ in $0.02 \%$ trypsin in $0.85 \% \mathrm{NaCl}$ at room temperature and rinsed in three changes of $4^{\circ} \mathrm{C}$ phosphate buffer, pH 6.8 (equal parts of $0.067 \mathrm{M}$ $\mathrm{Na}_{2} \mathrm{HPO}_{4}$ and $\left.0.067 \mathrm{M} \mathrm{KH}_{2} \mathrm{PO}_{4}\right)$. Staining was effected with $5 \%$ Giemsa solution for $45 \mathrm{~min}$.

Isozyme patterns - Isozymatic phenotypes from four systems were examined: glucosephosphate isomerase (GPI-5.3.1.9), phosphoglucomutase (PGM-2.7.5.1), isocitrate dehydrogenase (ICDH1.1.1.4.2.) and 6-phosphogluconate dehydrogenase (6-PGDH- 1.1.1.44). The isozymes were developed using the electrophoresis technique on cellulose acetate (Brown \& Knudson 1980). Cell samples were simultaneously run with adult and pupae extracts originating from the same colony. The current cell line's isozymatic patterns were compared to the Anopheles albimanus cell line LSBAA695BB (Bello et al. 1997). The only band or the band having the greatest migration distance from An. albimanus cell line sample was selected for each electrophoretic system as reference. It was given a value of 100 . The other bands' migration value were compared with the reference by using the ratio between their migration distance and that of the selected cell line multiplied by 100 .

Susceptibility to arbovirus - The susceptibility of the cell line to 12 arboviruses was tested; these viruses represent four different virus families; the infections were done in parallel with the Ae. albopictus cell line C6/36 (Igarashi 1978) and the Vero cell line (kidney fibroblasts from African green monkey). Each of the inoculated viruses, together with the identification of genus, family and known association with arthropods are given in Table I. Dilutions (1:10) of each stock virus were prepared; then $0.1 \mathrm{ml}$ of these was inoculated into each cell line. Infected mosquito cells were incubated at $28^{\circ} \mathrm{C}$, for a maximum time of 12 days.
However, infected tubes were extracted each $24 \mathrm{~h}$ as controls, to establish each virus' cycle. Subsequent to incubation time, the cells were separated, washed with PBS and impressions were taken in 18 -well slides. These slides were fixed in cold acetone for $10 \mathrm{~min}$ and were preserved frozen at $-70^{\circ} \mathrm{C}$ until the indirect immunofluorescence technique (IIF) was applied. In developing this technique, a specific hyperimmune antibody produced in mice (except for the EEV and EEE viruses, which used monoclonal antibodies) was prepared in 1:20 dilution. A measured $10 \mu \mathrm{l}$ of the immune reagents were added per well and incubated for $1 \mathrm{~h}$ at $37^{\circ} \mathrm{C}$. After this time, slides were washed three times with PBS and left to dry. Then $10 \mu$ of conjugate (anti-mouse IgG marked with fluorescein, diluted 1:80 in Evans blue 1:10,000) was added to each well, leaving them in incubation for $30 \mathrm{~min}$ at $37^{\circ} \mathrm{C}$. After this time, the slides were washed twice with PBS and once with distilled water. Then they were mounted with glycerine buffer to observe through the fluorescence microscope (Rey \& Ferro Bello 2000).

Sterility tests - Cell cultures were checked periodically for bacterial and fungal contamination. Two drops being taken from concentrated cells in the culture medium and then transferred (separately) to tubes containing heart-brain broth infusion and Sabouraud medium. The broth was incubated at $36^{\circ} \mathrm{C}$ for a week and the medium at room temperature for 15 days. The test for mycoplasm was done by the cytological method, staining with the fluorescent dye Hoeschst-33258 (Chen 1977, Cahoon et al. 1978, Oro 1984).

Cryopreservation - Culture semiconfluent monolayers were separated and the cells were adjusted to $5 \times 10^{6} / \mathrm{ml}$ in Grace's medium (Grace 1962), containing 20\% FBS and 10\% DMSO. The cell suspension was dispensed into sterile cryotubes and refrigerated at $5^{\circ} \mathrm{C}$ for $20 \mathrm{~min}$, then frozen at $-70^{\circ} \mathrm{C}$ overnight and, finally, put in liquid nitrogen for permanent storage.

\section{TABLE I}

Characteristics of the arboviruses used in the infection of the cell line PC-0199-BR

\begin{tabular}{lllll}
\hline Virus & Strain & Family & Genus & Vector \\
\hline VEE & V-263E & Togaviridae & Alphavirus & Mosquito \\
EEE & V-191 & Togaviridae & Alphavirus & Mosquito \\
Mayaro & Tr-VL4675 & Togaviridae & Alphavirus & Mosquito \\
Yellow fever & V-524 & Flaviviridae & Flavivirus & Mosquito \\
Dengue 2 & V-543 & Flaviviridae & Flavivirus & Mosquito \\
Dengue 3 & V-368 & Flaviviridae & Flavivirus & Mosquito \\
VSV & T-33894 & Rhabdoviridae & Vesiculovirus & Sand fly \\
Changuinola & BT-436 & Reoviridae & Orbivirus & Sand fly \\
\hline
\end{tabular}




\section{RESULTS}

Primary culture - Cell growth, from embryonated egg explants in different flasks, was first observed after about 71 days, as evidenced by isolated cells sticking to the surface of the flasks. The culture medium was MM/VP12, supplemented with FBS at an initial 20\% concentration, and a $\mathrm{pH}$ ranging from 6.3 to 6.8 . At the beginning, cell growth was slow but after two months, the cell groups formed colonies, that adhered to the surface of the flask. Some, more numerous, occupied relatively greater space and closer relationship to tissue fragments, proliferating more rapidly and, consequently, increasing in number. Others fewer cells limited to small areas wich had restricted growth. A third group had only few colonies, limited to the corners of the flasks even fewer cells than the previous ones which finally were not viable and degenerated, sites being observed (at the end of two weeks) marked with cell vestiges. However, at the end of the fourth week, after growth had begun, the first two groups of colonies had expanded and occupied two-thirds of the flask's surface.

The formation of vesicles was observed in the third week of the previous event. Some were suspended in the culture medium and others adhered to the extremes of the tissue fragments. Vesicles disintegration was accomplished by vigorous pipetting of the medium, an operation effected in another sterile flask whose contents were returned to the original culture with an additional $2 \mathrm{ml}$ fresh medium. A confluent monolayer was achieved 5 months after the embryonated egg explants. The first attempts to subculture the cells failed. However, after changing MM/VP12 for Grace's medium the first subculture was successfully achieved.

Cell line - In the first three subcultures, cell growth was slow, an average duration of 30 days between a subculture and other. From the fourth passage onwards, the duration between subcultures was gradually diminished until reaching 8 days. Subcultures were maintained in Grace's medium, supplemented with $20 \%$ FBS, having 6.5 to 7.0 $\mathrm{pH}$, in the first 10 passages; then the $20 \%$ concentration was gradually reduced to $15 \%$ and finally to $10 \%$. Currently, 62 passages have been recorded, and the cell line has been designated PC-0199-BR (Fig. 1). Cells no show evidence of contamination with bacteria, fungi or mycoplasma. Cell cultures were successfully grown in L-15 medium (Leibovitz 1963) and in a mixture of equal parts of Grace and L-15; however, they did not grow in MM/VP12 medium.

Cell morphology - Cell forms in the primary cultures varied, consisting of small spheres, layer

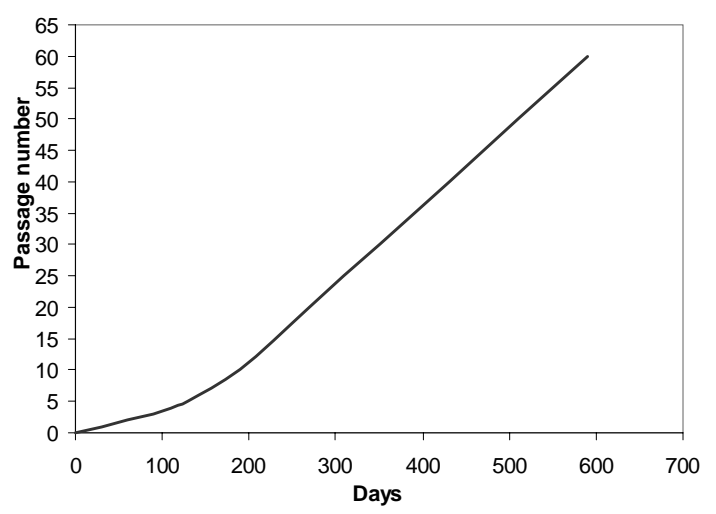

Fig.1: passage numbers effected in the cultured cells of Psorophora confinnis within time intervals.

epithelial, irregular, gigantic and fibroblastic; nevertheless, after the 10th subculture, the cells in the monolayer were predominantly epithelioid with few fibroblastic forms (Fig. 2).

Growth characteristics - The time for the population doubling at $28^{\circ} \mathrm{C}$ was $26 \mathrm{~h}$ with an initial density of $2 \times 10^{5}$ cells $/ \mathrm{ml}$. Optimal cell proliferation was obtained at a temperature of $28^{\circ} \mathrm{C}$, without $\mathrm{CO}_{2}$ atmosphere. The best FBS concentration for cell growth and maintenance was $10 \%$.

Cytogenetic characteristics - The number of diploid chromosomes in metaphase was predominantly $6(2 \mathrm{n}=6)$ (Fig. 3A). Tetraploidy (5\%) (Fig. 3B) and aneuploidy (1\%) (Fig. 3C) were also recorded in passages greater than 20. Chromosome measurements in microns are indicated in Table II.

Using the C-banding technique, the constitutive heterochromatin region associated with the centromere (Fig. 3D) were identified.

The $\mathrm{G}$ banding patterns are shown in Fig. 4 . The average number of bands for each one of the chromosomes of the karyotype were the following: 4 to 5 bands for chromosome $1 ; 6$ to 7 bands for chromosome 2; and 8 to 9 bands for chromosome 3.

Isoenzyme analysis - PC-0199-BR isozymatic phenotypes corresponding to the four analysed systems coincided with those obtained from pupae and adult samples belonging to the same species and colony. Average values for electrophoretic mobility relating to each one of the isozymatic systems is shown in Table III.

Assays with arboviruses - Mayaro, vesicular stomatitis, VEE and EEE viruses replicated in the PC-0199-BR cell line. No multiplication of changuinola, dengue- 2 , dengue- 3 and yellow fever viruses occurred during the 12 days of cell culture. The PC-0199-BR cultures were especially 
sensitive to the EEV and EEE viruses, whose antigens could be detected on the first post-infection day, but the percentage of infection, as well as fluorescence intensity, was optimum $96 \mathrm{~h}$ after inoculation. None of the arboviruses used in the assays produced cytopathic effects. The C6/36 cell lines was used as control for the mayaro, vesicular stomatitis, dengue (two subtypes) and yellow fever virus infections, the Vero cell line served as control for the EEV and EEE viruses. These viruses were viable and multiplied in the $\mathrm{C} 6 / 36$ or Vero cell lines.

\section{DISCUSSION}

The greatest problem, as described in a previous study (Bello et al. 1999), was the inability to get PC-0199-BR subcultures to grow serially in
MM/VP12 medium. Although primary cultures were obtained in this medium relatively easily, the cells did not subculture, lost their viability and degenerated. This problem was resolved by replacing the MM/VP12 with Grace's medium, indicating that the latter medium provided the necessary nutrients for the cells to grow and proliferate through the subsequent subcultures, which have been maintained for about 20 months. This is the first report of a continuous cell line from the genus Psorophora.

The primary cell cultures began growth after a relatively long time, compared to other cultures derived from mosquitoes (Oelofsen et al. 1990, Pant et al. 1992, Charpentier et al. 1995, Bello $1995,1997)$. This was probably due to the difficulty that the cells had in adapting to the medium's

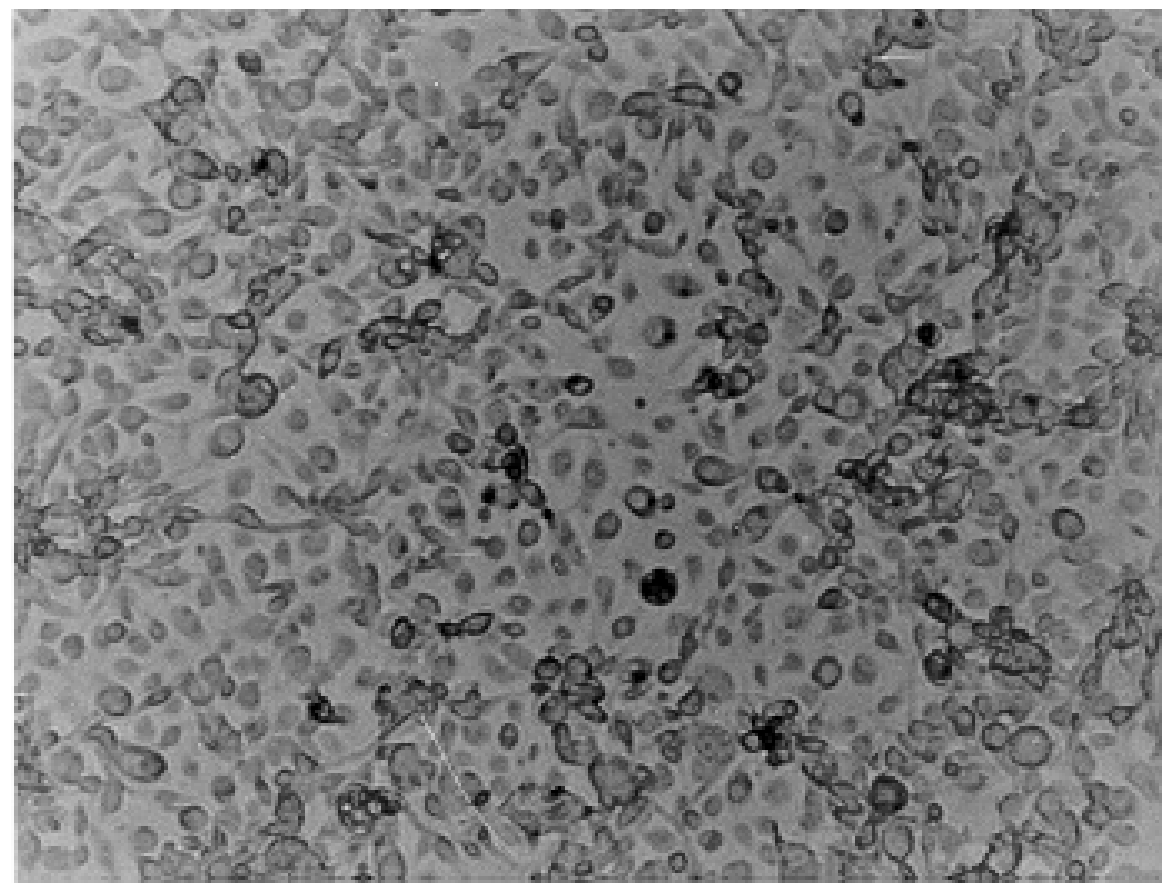

Fig. 2: monolayer of PC-0199-BR, showing the predominantly epithelioid cell population of passage 51, four days after subculture.

TABLE II

Average chromosomal measurements of metaphases derived of the cultured cells, PC-0199-BR, were done at passages 19 and 21

\begin{tabular}{cccccccccc}
\hline & $\mathrm{p}$ & $\mathrm{q}$ & $\mathrm{TL}$ & $\mathrm{RL}$ & $\mathrm{q} / \mathrm{p}$ & $\mathrm{p} / \mathrm{q}$ & $\mathrm{CI}$ & $\mathrm{RLC}$ & $\mathrm{n}$ \\
\hline Chromosomes 1 & $1.462 \pm 0.004$ & $1.462 \pm 0.004$ & $3.821 \pm 0.005$ & 0.292 & 1.000 & 1.000 & 0.381 & 1.000 & 20 \\
Chromosomes 2 & $1.851 \pm 0.006$ & $2.123 \pm 0.005$ & $4.317 \pm 0.006$ & 0.339 & 1.146 & 0.871 & 0.428 & 1.126 & 20 \\
Chromosomes 3 & $2.211 \pm 0.004$ & $2.685 \pm 0.006$ & $4.939 \pm 0.004$ & 0.377 & 1.214 & 0.823 & 0.447 & 1.289 & 20 \\
\hline
\end{tabular}

p: short arm; q: long arm; TL: total length; RL: relative length; CI: centromeric index; RLC: relative length of the chromosomes; n: number of metaphases; mean $\pm \mathrm{SE}$ 
A

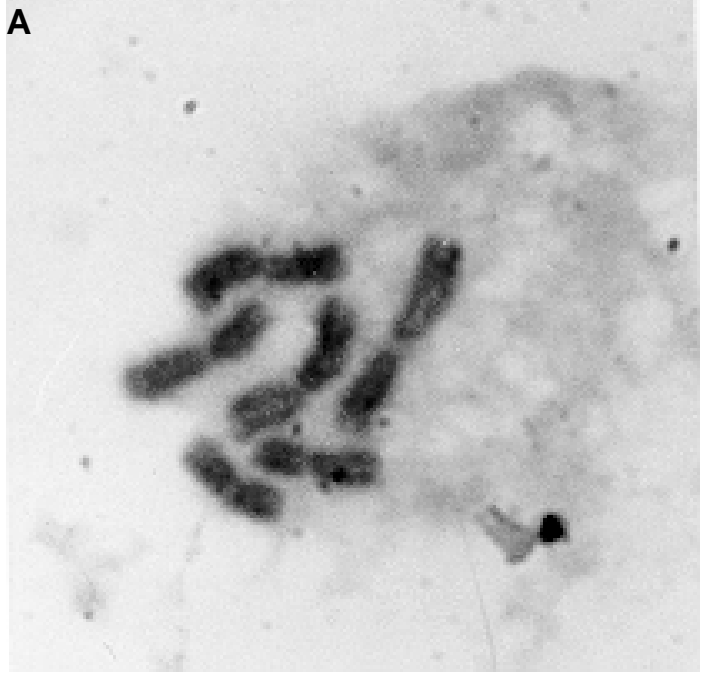

C

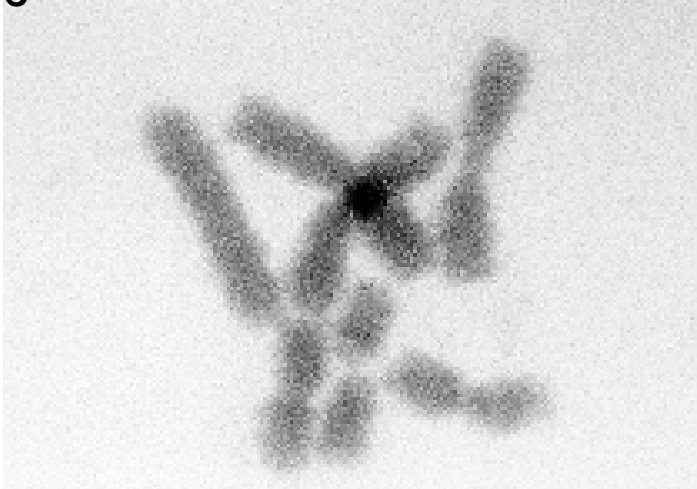

B

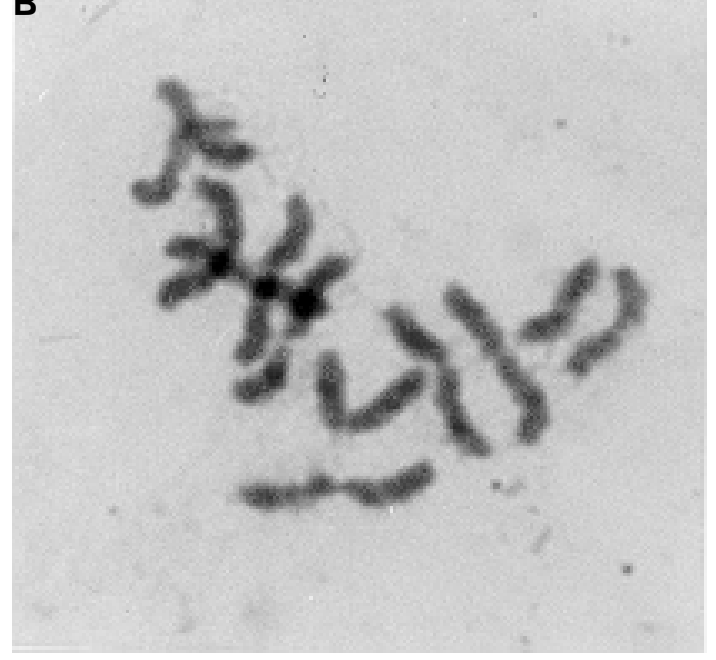

D

Fig. 3: karyotypes of Psorophora confinnis cultured cells showing. A: metaphase with the normal diploid number; B: tetraploidia $(4 n=12)$ from a cell in passage 53 ; C: aneuploid metaphase with an extra chromosome 1; D: karyotype treated to develop technique C-bands.

conditions. Embryonated eggs having 2/3 embryogenesis (Charpentier et al. 1995) and an average quantity of 650 eggs (Pant et al. 1992) (in addition to the medium's favourable physical-chemical conditions) are the optimum conditions for initiation of cell growth in a relatively short time.

Optimal temperature for the cell culture (developed with the present species) was $28^{\circ} \mathrm{C}$, similar to that observed in most cell lines derived from mosquitoes (Leake 1997). However, the viability of cells incubated at room temperature in the laboratory (averaging $17^{\circ} \mathrm{C}$ ) was seen in assays during many passages [a situation previously reported by
Peleg and Pecht (1978)]. Under these conditions, slight morphological changes in the cells were observed in association with greater time to reach confluence in the monolayer. The same did not occur with cultures incubated at $37^{\circ} \mathrm{C}$. These cells did not grow, detaching themselves from one another and losing their capacity for subculture.

The technique used to sterilize the eggs' surface in normal conditions (prior to seeding the explants) was with sodium hypochlorite and ethanol solutions, according to the procedure described by Tesh (1980). Occasionally mercuric chloride solution was necessary for surface sterilization of adult mosqui- 


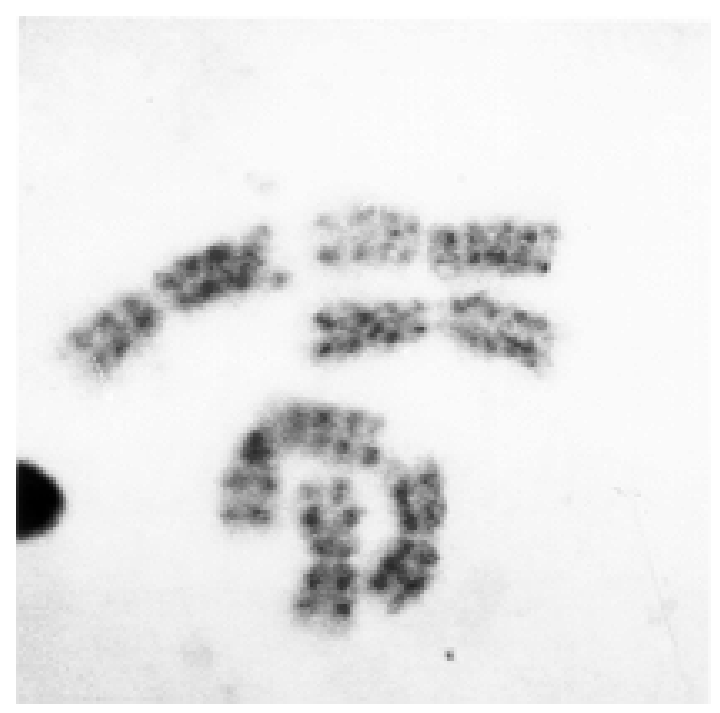

Fig. 4: chromosomes in mitotic metaphase, from a cultured cell of Psorophora confinns (PC-0199-BR) showing that all three pairs exhibit clear G-bands along the entire length of the chromosomes.

TABLE III

Relative isozymatic mobilities in each of the analyzed samples, comparing culture fresh cells with organism of Psorophora confinnis

\begin{tabular}{|c|c|c|c|c|}
\hline \multirow[b]{2}{*}{ Samples } & \multicolumn{4}{|c|}{ Isozyme } \\
\hline & GPI & PGM & 6-PGDH & ICDH \\
\hline PC-0199-BR ${ }^{a}$ & 104.5 & 89.5 & 90.4 & $\begin{array}{r}131.9 \\
52.4\end{array}$ \\
\hline Adults & 104.1 & 89.3 & 90.2 & $\begin{array}{r}131.2 \\
52.0\end{array}$ \\
\hline Pupae & 104.3 & 89.1 & 90.1 & $\begin{array}{r}131.5 \\
52.3\end{array}$ \\
\hline LSB-AA695BB ${ }^{b}$ & 100.0 & 100.0 & 100.0 & $\begin{array}{r}100.0 \\
49.1\end{array}$ \\
\hline
\end{tabular}

$a: P$. confinnis cell line; $b$ : Anopheles albimanus cell line. In this sample, the only band obtained in each of three isozymatic systems and the band that had the greatest migration distance in other system (ICDH) were selected as references and given values of 100 .

toes (Hsu et al. 1970). This was because the time required to execute the first procedure was relatively greater, and in eggs with advanced embryogenesis caused eggs to hatch before sterilization was completed. This was observed to a lesser extent with the mercuric chloride solution.

The primary cultures had cells of heterogeneous forms and sizes, a condition also reported by other researchers (Lee \& Hou 1992, Charpentier et al. 1995, Lucas \& Nagan Le Meillour 1997, McIntosh et al. 1999, Rey \& Ferro Bello 2000). However, after a number of subcultures, the cells assumed a defined shape and size. At present, they are predominantly epitheliod; cell size is greater that of the C6/36 clone derived from Ae. albopictus (Igarashi 1978), Ae. taeniorhynchus (Bello et al. 1995), An. albimanus SB-AA695BB (Bello et al. 1997) and Lutzomyia longipalpis (Tesh 1983, Rey \& Ferro Bello 2000) cell lines.

The cells' diploid chromosome number was 6 , coinciding with that recorded for the species by Breland (1961). Based on direct measurements and the centromere position (C-bands), pair 1 was metacentric and of shortest length, whilst pairs 2 and 3 were slightly submetacentric and longer. This classification does not differ from the general uniform pattern for the Culicinae and Toxorhynchitinae subfamily karyotypes, where pair 1 is shorter and pairs 2 and 3 are of almost equal length (Clements 1992). One or both of the longer chromosome pairs can be slightly sub-metacentric, i.e., with one of the arms slightly shorter than the other (Kitzmilller 1967). The average number of G-bands was similar to that established for the species, from brain tissue of late 4th instar larvae (Hernández et al. 2000).

PC-0199-BR isozymatic phenotypes coincided with the pupae and adult samples originating from the same colony, demonstrating that the cells in the cultures were derived from the original species. When this cell line's isozymatic profile was compared with that of An. albimanus, differences characteristic for each were established, inferring the absence of contamination.

The preliminary study of PC-0199-BR infection with some arboviruses, demonstrated that this cell line can be an important substrate for alphavirus replication, especially those related to encephalitis, even though it can also (in agreement with the results) be useful for vesiculovirus multiplication. Though the VEE and EEE viruses multiplied well in Vero cells (producing a cytopathic effect), this new cell line constitutes an alternative substrate for understanding ecological relationships between the virus and its vector. Because of the case of infection and manipulation, the cell culture will provide insights into differences between the epidemic-epizootic and epidemic-enzootic cycles of VEE and EEE.

\section{ACKNOWLEDGEMENTS}

To Dr Robert Tesh, Professor, Department of Pathology, Center for Tropical Diseases, University of Texas Medical Branch, for his valuable comments and for reading the original manuscript. 


\section{REFERENCES}

Bello FJ, Boshell J, Rey G, Morales A, Olano VA 1995. Initiation of primary cell cultures from embryos of the mosquitoes Anopheles albimanus and Aedes taeniorhynchus (Diptera: Culicidae). Mem Inst Oswaldo Cruz 90: 547-551.

Bello FJ, Brochero H, Boshell J, Olano V, Rey G 1997. Establishment and characterization of a cell line from the mosquito Anopheles albimanus (Diptera: Culicidae). Mem Inst Oswaldo Cruz 92: 123-128.

Bello F, Rodríguez J, Morales A, Olano V 1999. Estudio de cultivos celulares primarios de Psorophora confinnis (Diptera: Culicidae). Biomédica 19: 127 135.

Breland OP 1961. Studies on the chromosomes of mosquitoes. Ann Entomol Soc Am 54: 360-375.

Brown JE, Knudson DK 1980. Characterization of invertebrate cell lines. III. Isozyme analyses employing cellulose-acetate electrophoresis. In vitro Cell Dev Biol 16: 829-833.

Cahoon BE, Hardy JL, Reeves WC 1978. Initiation and characterization of a diploid cell line from larval tissues of Aedes dorsalis (Meigen). In vitro Cell Dev Biol 14: 255-260.

Charpentier G, Belloncik S, Ducros G, Fontenille D, Tian L, Quiot JM 1995. Establishment and characterization of three cell lines from Aedes triseriatus (Diptera: Culicidae). J Med Entomol 32: 793-800.

Chen TR 1977. In situ detection of mycoplasma contamination in cell culture by fluorescent Hoeschst33258 stain. Exp Cell Res 104: 255-262.

Clements AN 1992. The Biology of Mosquitoes. Development, Nutrition and Reproduction, Vol. 1, Chapman \& Hall, London, 509 pp.

Dickerman W, Cupp EW, Groot H, Morales A, Cura E, Dickerman AW, Ibagos AL, Rico-Hesse R, Taylor CA, Weaver SC 1986. Venezuelan encephalitis virus activity in northern Colombia during April and May 1983. Bull PHAO 20: 276-283.

Forattini OP 1965. Entomología Médica, Vol. 2, Universidad de São Paulo, São Paulo, p. 422-428.

Gelernter WD, Federici BA 1986. Contnuous cell line from Spodoptera exigua (Lepidoptera: Noctuidae) that supports replication of nuclear polyhedrosis viruses from Spodoptera exigua and Autographa californica. J Invertebr Pathol 48: 199-207.

González C 1995. Mosquitos de Caño Limón, Arauca (Diptera: Culicidae), Thesis, Universidad Nacional de Colombia, Bogota, p. 150-153.

Grace TDC 1962. Establishment of four strains of cells from insect tissues grown in vitro. Nature 195: 788789.

Grace T 1966. Establishment of a line of mosquito (Aedes aegypti L) cells grown in vitro. Nature 211: 366-367.

Greany PD 1991. Innovations in culturing cells, tissues, and endoparasites of invertebrates. In Vitro Cell Dev Biol 27: 469.

Hernández C, Reyes E, Rodríguez J, Olano V, Morales A, Bello F 2000. Comparación citogenética de Psorophora confinnis (Diptera: Culicidae) en cepas representativas de dos poblaciones colombianas. Biomédica 20: 218-227.
Hsu SH, Mao WH, Cross JH 1970. Establishment of a line cells derived from ovarian tissue of Culex quinquefasciatus Say. J Med Entomol 7: 703-707.

Igarashi A 1978. Isolation of a Singh's Aedes albopictus cell clone sensitive to dengue and chikungunya viruses. J Gen Virol 40: 531-544.

Kitzmiller JB 1967. Mosquito cytogenetics. In JW Wright, R Pal (eds), Genetics of Insect Vectors of Disease, Elsevier, Amsterdam, p. 133-150.

Kurtti TJ, Munderloh UG 1994. Mosquito cell culture. In K Maramorosch, Advances in Cell Cultures, Vol. 3, Academic Press, New York, p. 259.

Leake CJ 1997. Establishing primary cell cultures from disease vectors and maintenance of continuous cell lines. In JM Crampton, CB Beard, C Louis (eds), The Molecular Biology of Insect Disease Vectors, Chapman \& Hall, London, p. 487.

Lee S, Hou R 1992. Establishment of a cell line derived from embryos of the Diamondback moth, Plutella xylostella (L). J Invertebr Pathol 59: 174-177.

Leibovitz A 1963. The growth and maintenance of tissue-cell cultures in free gas exchange with the atmosphere. Am J Hygiene 78: 173-180.

Lucas P, Nagnam Le Meillour P 1997. Primary culture of antennal cells of Mamestra brassicae: morphology of cell types and evidence for biosynthesis of pheromone-binding proteins in vitro. Cell Tissue Res 289: 375-382.

Marchi A, Mezzanote R, Ferrucci L 1980. Characterization of the metaphase chromosomes in Anopheles stephensi (Liston, 1901) by Q, G and C banding. Cytologia 45: 549-553.

McCarthy WJ, Hatfield T, McMahon S 1987. Effects pesticides on division of two lepidopteran cell lines and on Autographa californica MNPV development in TN368 cells. In Vitro Cell Dev Biol 23: 621-626.

McIntosh AH, Christian PD, Graseia JJ 1999. The establishment of heliothine cell line and their susceptibility to two baculoviruses. In vitro Cell Dev Biol 35: 94-97.

Motara MA, Rai KS 1978. Giemsa C-banding patterns in Aedes (Stegomyia) mosquitoes. Chromosoma (Berl.) 70: 51-58.

Oelofsen MJ, Gericke A, Smith MS, De K Van der Linde TC 1990. Establishment and characterization of a cell line from the mosquito Culex (Culex) theileri (Diptera: Culicidae) and its susceptibility to infection with arboviruses. J Med Entomol 27: 939-944.

Olano VA, Morales A 1981. Colonización de una cepa de Psorophora (Grabhamia) confinnis Arribalzaga 1891, en Colombia. Biomédica 1: 12-15.

Oro G 1984. Establishment of a mosquito cell line from Haemagogus equinus larvae. In vitro Cell Dev Biol 20: 153-156.

Pant U, Mourya DT, Sudeep AB, Banerjee K, Dhanda $\mathrm{V}$ 1992. New embryonic cell line from Aedes krombeini (H.) (Diptera: Culicidae). In vitro Cell Dev Biol 28: 567-568.

Peleg J, Pecht M 1978. Adaptation of an Aedes aegypti mosquito cell line to growth at $15^{\circ} \mathrm{C}$ and its response to infection by Sindbis virus. J Gen Virol 28: 231.

Pudney M, Varma MGR 1971. Anopheles stephensi Var. 
Mysorensis: establishment of a larval cell line (Mos. 43). Exp Parasitol 29: 7-12.

Rey G, Ferro Bello F 2000. Establishment and characterization of a new continuous cell line from Lutzomyia longipalpis (Diptera: Psychodidae) and its susceptibility to infections with arboviruses and Leishmania chagasi. Mem Inst Oswaldo Cruz 95: 103-110.

Rivas F, Díaz L, Cárdenas M, Daza E, Bruzon L, Alcalá A, De La Hoz O, Cáceres F, Aristizabal G, Martínez J, Revelo D, De La Hoz F, Boshell J, Camacho T, Calderón L, Olano V, Villareal L, Roselli D, Alvarez G, Ludwig G, Tsai T 1997. Epidemic Venezuelan equine encephalitis in La Guajira, Colombia. J Infect Diseases 175: 828-832.

Sanmartín C, Groot H, Osorno-Mesa E 1954. Human epidemic in Colombia caused by the Venezuelan Encephalomyelitis Venezolana virus. Am J Trop Med Hyg 3: 283-293.

Sanmartín C, Mackenzie RB, Trapido H, Barreto P, Mullenax CH, Gutiérrez E, Lesmes C 1973. Encefalitis Equina Venezolana en Colombia. Bol Ofic Sanit Panam 74: 108-137.

Sudia WD 1972. Arthropod Vectors of Epidemic Venezuelan Equine Encephalitis, PAHO, Washington
D.C., p. 157-169.

Schneider I 1987. Preparation and maintenance of arthropod cell culture: Diptera, with emphasis on mosquitoes. In CE Yunker, Arboviruses in Arthropod Cells in Vitro, Vol. 1, CRC Press, Boca Raton, Fl, p. 31.

Seabright M 1971. A rapid banding technique for human chromosomes. Lancet 2: 971-972.

Shotkoski FA, Fallon AM 1994. Expresion of an antisense dihydrofolate reductase transcript in transfected mosquito cells: effects on growth and plating efficiency. Am J Trop Med Hyg 50: 433-439.

Tesh R 1980. Establishment of two cell lines from the mosquito Toxorhynchites amboinensis (Diptera: Culicidae) and their susceptibility to infection with arboviruses. J Med Entomol 17: 338-343.

Tesh R, Modi G 1983. Development of a continuous cell line from the sand-fly Lutzomyia longipalpis (Diptera: Psychodidae), and its susceptibility to infections with arboviruses. J Med Entomol 20: 199202.

Weaver SC, Salas R, Rico-Hesse R, Ludwig GV, Obereste MS, Boshell J, Tesh RB 1996. Re-emergence of epidemic Venezuelan equine encephalomyelitis in South America. Lancet 348: 436-440. 